\title{
A SUPRAGLACIAL EXTENSION OF AN ICE-DAMMED LAKE, TUNSBERGDALSBREEN, NORWAY
}

\author{
By Philip J. Howarth* \\ (Department of Geography, University of Glasgow, Glasgow, Scotland)
}

\begin{abstract}
Observations on Tunsbergdalsbreen show that an ice-dammed lake, Store Brimkjelen, overflowed on to the surface of the glacier. The lake lifted a section of the glacier and formed a long irregular crevasse along the line of dislocation.

RÉsumé. Extension supra-glaciaire d'un lac d'un barrage de glace, Tunsbergdalsbre, Noriège. Des observations faites au Tunsbergdalsbre montrent qu'un lac de barrage glaciaire. Store Brimkjelen, inonda la surface du glacier. Le lac souleva une partie du glacier et forma une longue crevasse irrégulière le long de la ligne de dislocation.

Zusammenfassung. Ausdehnung eines Eisstausees am Tunsbergdalsbre, Norwegen, auf das Gletschereis. Beobachtungen am Tunsbergdalsbre zeigen, dass ein Eisstausee, der Store Brimkjelen, die Gletscheroberfläche überflutet hat. Der See hat einen Teil des Gletschers hochgchoben; an der Hebungslinie bildete sich eine lange unregelmässige Gletscherspalte.
\end{abstract}

\section{INTRODUCTION}

Between 1956 and 1964 , the Brathay Exploration Group, in consultation with Dr J. F. Nye, undertook a programme of glaciological investigations on Tunsbergdalsbreen, the largest outlet glacier in Norway. As part of this project, the author studied an ice-dammed lake, Store Brimkjelen, situated on the western margin of the glacier. This paper considers the development of a supraglacial extension of the lake that was formed in 1962 .

\section{Tunsbergdalsbreen and Store Brimkjelen}

Tunsbergdalsbreen (lat. $61^{\circ} 35^{\prime} \mathrm{N}$., long. $7^{\circ}$ 05' E.) flows south from the ice cap of Jostedalsbreen, located between the Nordfjord and the Sognefjord on the west coast of Norway. Its valley section, from the edge of the ice cap to the snout, is approximately $13 \mathrm{~km}$ long, and over this distance its width varies between $\mathrm{I} 000 \mathrm{~m}$ and $1700 \mathrm{~m}$. The snout of the glacier rests on a rock bar and the main outlet stream occupies a gorge cut through the rock bar.

Brimkjelen forms a branch valley of Tunsbergdalsbreen, the sides and headwall of which are extremely steep. The valley is situated on the west side of Tunsbergdalsbreen below a low ice fall, a distance of $45^{\circ 0}$ metres from the snout of the glacier. Tunsbergdalsbreen widens as Brimkjelen joins the main valley, and ice from the western side of the glacier turns to flow towards the side valley. The ice ends in a steep cliff, which produces the dam for the lake. An indication of the ice flow towards the side valley is given by a medial moraine which curves from south through to south-west to end in the crevassing close to the ice cliff (Fig. I).

\section{The Development of Store Brimkjelen}

The retreat of the glacier that occupied Brimkjelen has been comparatively rapid. In 1903 it was still in contact with Tunsbergdalsbreen (Rekstad, 1911, p. 15). By 1937 it had retreated to the head of the lake then occupying the valley (Pillewizer, 1952), and all that remains at present is a narrow glacier tongue suspended above the headwall of the valley.

Records of outbursts from the lake have been well documented. Every year between 1896 and 1900 , and again in 1903 , floods occurred in the Leirdal river draining from the glacier (Liestøl, I956, p. 132). In 1900 and 1903 , Rekstad (1901, I904) visited the glacier to try to determine the cause of the flooding.

* Present address: Department of Geography, McMaster University, Hamilton, Ontario, Canada. 
The flood of 1900 took place on 6 August. When Rekstad visited the glacier in September, he found that the surface of the ice in the inner part of Brimkjelen was approximately $100 \mathrm{~m}$ lower than the main glacier of Tunsbergdalsbreen and was badly broken up (Rekstad, I9or, p. 83 ). He suggested that the ice in Brimkjelen had sunk into the bottom of the valley after a lake, formed beneath the glacier, had drained. As there was no evidence that the water had flowed over the surface of the glacier, he considered that the lake must have drained through a tunnel underneath Tunsbergdalsbreen (Rekstad, I901, p. 85).

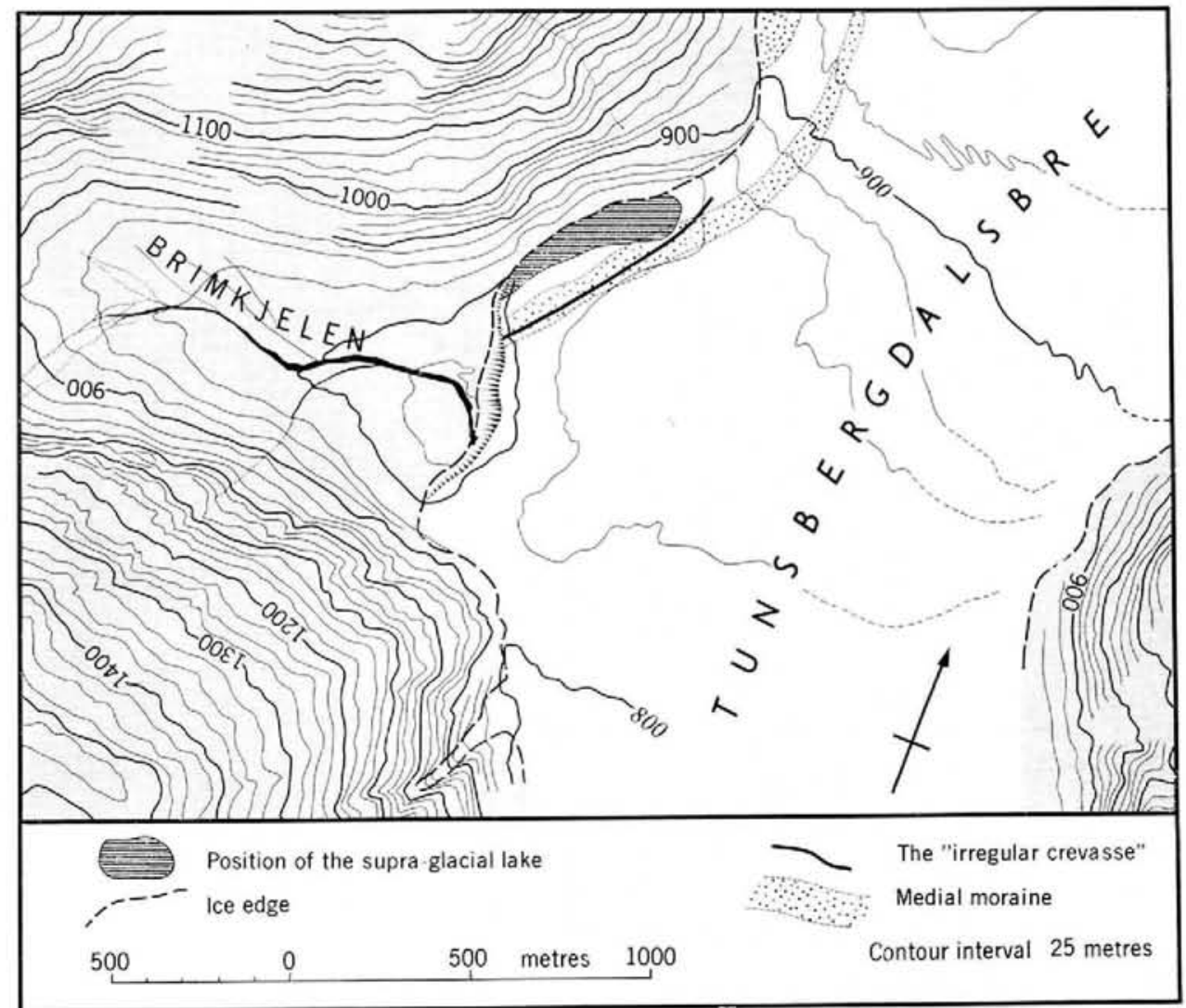

Fig. 1. The location of Brimkjelen. The positions of the supraglacial extension of the lake and the irregular crevasse have been superimposed on the map produced by Kick $(1966)$.

In I903, a severe flood occurred on 22-23 August which destroyed a bridge over the Leirdal river (Rekstad, I904, p. I). Rekstad visited Tunsbergdalsbreen in September of that year and again found that in the inner part of Brimkjelen, the ice had sunk into the bottom of the valley. On this visit, he also observed that a large crevasse had been formed where the glacier from Brimkjelen joined with Tunsbergdalsbreen. At the crevasse, the surface of Tunsbergdalsbreen was 5 to $10 \mathrm{~m}$ higher than the ice flowing from Brimkjelen (Rekstad, I904, p. 2-3).

The effects of a severe flood in 1926 were observed by Ingstad (1927). Gravel and boulders were carried into the Jostedal (a distance of approximately $14 \mathrm{~km}$ from the snout of the glacier) causing the river in that valley to be dammed and a lake to be formed. Ingstad reckoned that 25 to 30 million cubic metres of water must have been released from Brimkjelen during this flood. 
The ice-dammed lake was mapped for the first time in 1937 by Finsterwalder and others as part of a photogrammetric survey of the glacier (Pillewizer, 1952). The survey was repeated by Kick and Dorrer in 1961 , at which time the lake did not occupy the valley, and it was calculated that in 1937 , Store Brimkjelen must have held 19.2 million cubic metres of water (Kick, 1966, p. 9).

A map of the glacier at a scale of I : 20000 was also published in I 966 by the Hydrologisk Avdeling of Norges Vassdrags- og Elekrisitetsvesen (Otnes and Ostrem, 1967). The map of the lower half of the glacier, based on vertical acrial photography flown in 195.5. provides additional information on the downwastage of the glacier surface.

Since 1937 , and perhaps earlier, the ice cliff has maintained virtually the same position in relation to the valley of Brimkjelen that it has today, forward movement of the glacier being balanced by collapse from the ice cliff. In spite of this, the glacier has shown general downwastage of its surface, concurrent with the retreat of its snout. On the map of Tunsbergdalsbreen produced by Kick (1966), it can be seen that the ice surface in the area of Brimkjelen has been lowered by approximately $50 \mathrm{~m}$ in 24 years. This figure amounts to almost $60 \mathrm{~m}$ close to the northern wall of Brimkjelen, the increased ablation probably being due to the effect of heat from the valley side. The result has been gradually to increase the angle of slope of the glacier surface close to the northern wall of Brimkjelen and to form a depression running east west between the ice surface and the valley side.

A topographic map of Jostedalen, at a scale of $1: 50000$ and based on vertical acrial photography flown in 1966, is to be published soon by the Norges Geografiske Oppmáling. A blue-print of this map, which includes almost the entire area of Tunsbergdalsbreen, has been kindly sent to the author by Dr Ostrem. On the map, the $800 \mathrm{~m}$ contour in the area of Brimkjelen clearly indicates the depression formed between the glacier and the valley side. This depression was occupied by a supraglacial extension of Store Brimkjelen, formed in 1962.

\section{Observations in ig62}

In August 1962, the floor and sides of Brimkjelen were filled with blocks of ice. The lake which had deposited these icebergs had drained, although water could be seen in the very bottom of the valley amongst the icebergs close to the ice cliff. The upper limit of deposition of icebergs formed a very regular line, clearly indicating the maximum height of the lake (Fig. 2). From the contours on the map produced by Kick (1966), it is estimated that the height of the lake surface was approximately $8 \mathrm{I}_{5} \mathrm{~m}$ a.s.l.

As well as filling part of the valley, it was apparent that the water had overflowed on to the surface of the glacier. The supraglacial extension of the lake had occupied the depression between the surface of the glacier and the valley side (Fig. 1). The rise of the ice surface away from the valley side had prevented drainage from the lake over the surface of the glacier.

Large blocks of clean, white ice, some at least $5 \mathrm{~m}$ high, had been deposited on the surface of the glacier. The largest blocks can be seen at the bottom of Figure 2, close to the edge of the glacier. A number of the smaller blocks of ice had formed "glacier tables" by protecting the underlying pedestal of surface ice from melting (Fig. 3). Whether the height of the pedestal represents the ablation that had occurred after the lake had drained, it is impossible to say, for the ice blocks could easily have slipped more than once. From the contours on the map produced by Kick ( 1966 ), however, the depression at the edge of the glacier would easily have permitted blocks of ice to be floated on to the surface of the glacier, assuming the height of the lake surface to have been approximately $815 \mathrm{~m}$.

In addition to the ice blocks, the surface of the glacier indicated the former presence of water, areas of it having been washed clean of the finer debris. The ice in these parts had a crenulated micro-relief, similar to that produced in areas of small, shallow, slow-flowing supraglacial streams. It suggests that perhaps the water had only recently vacated this part of the ice. 


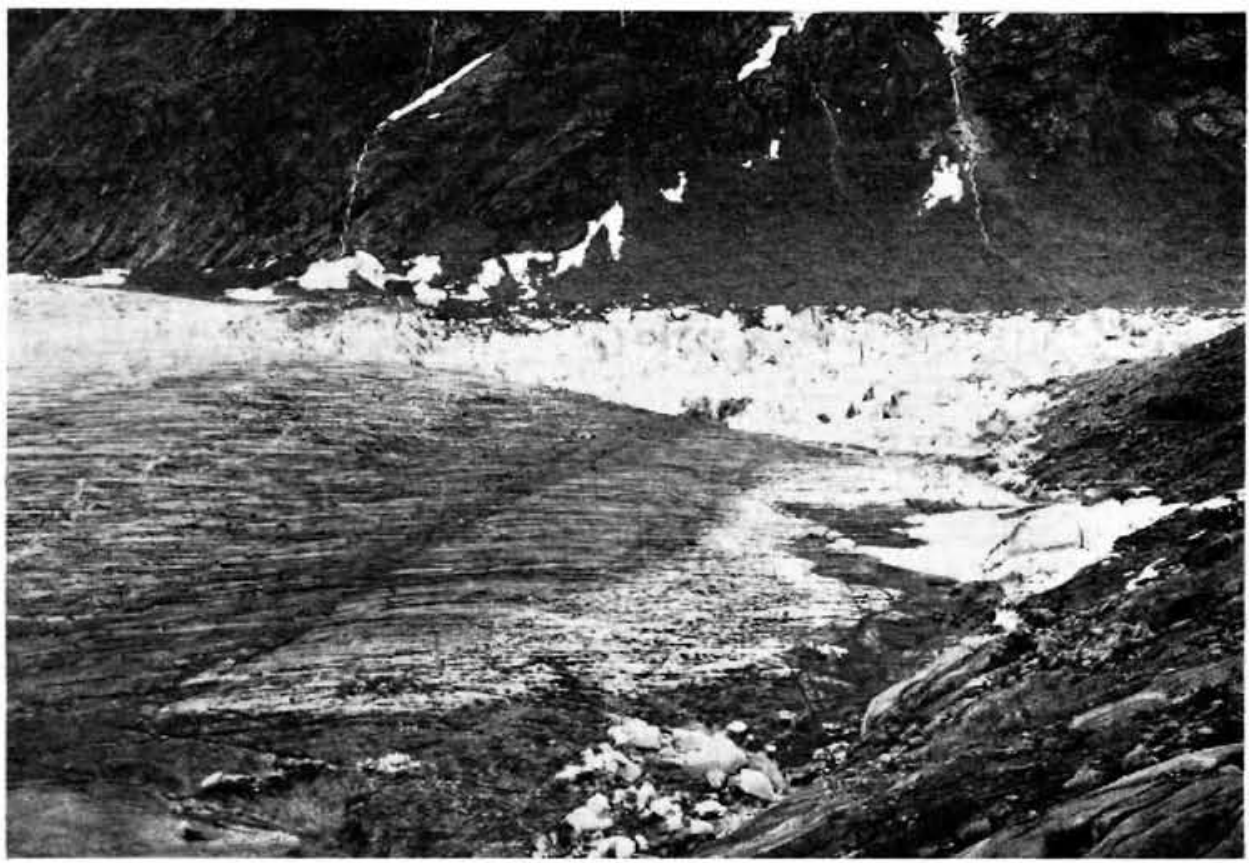

Fig. 2. Brimkjelen from the northern side of the valley. The height of the lake which occupied the valley is indicated by the upper limit of deposition of icebergs. Icebergs deposited on the surface of the glacier by the supraglacial extension of the lake can be seen at the bottom of the photograph. Part of the irregular crevasse runs down the centre of the medial moraine at the left side of the photograph.

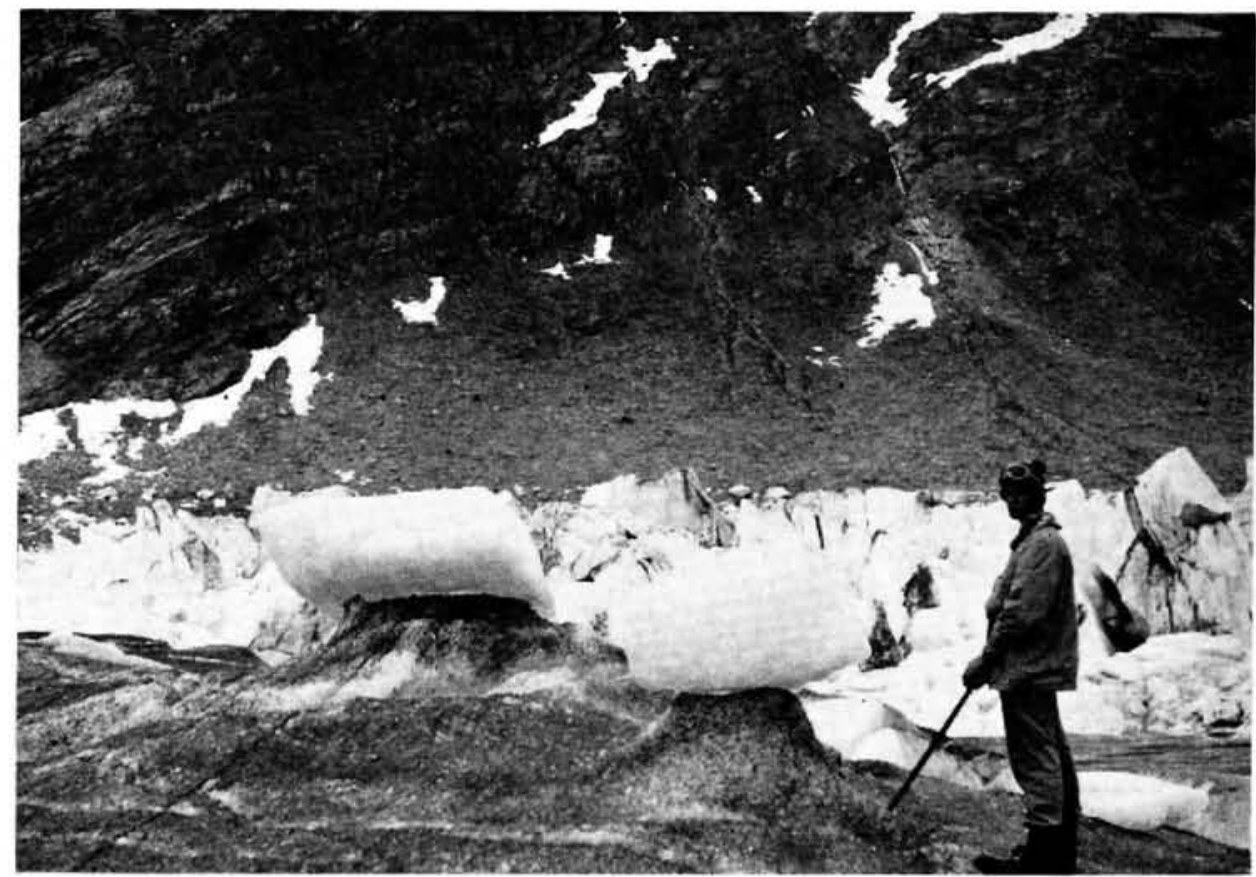

Fig. 3. "Glacier tables" formed by small icebergs of white ice deposited on the glacier surface by the lake. 
The most important effect of the water was to cause bodily movement of the glacier. A whole section of the glacier appeared to have been lifted by the lake, and an irregular crevasse (Figs. I and 4) indicated the line of dislocation, which resulted from this movement. The crevasse ran from the base of the ice fall (in the middle distance of Figure 4) to the ice shelf above Brimkjelen, where it was at least $200 \mathrm{~m}$ from the side of the valley. The normal crevasses in this part of the glacier are longitudinal, meeting the valley side at angles of at least $60^{\circ}$. In contrast to this, the irregular line of dislocation ran almost at right angles to the normal crevasse pattern. Dislocation of the ice had also occurred at the edge of the glacier. Here,

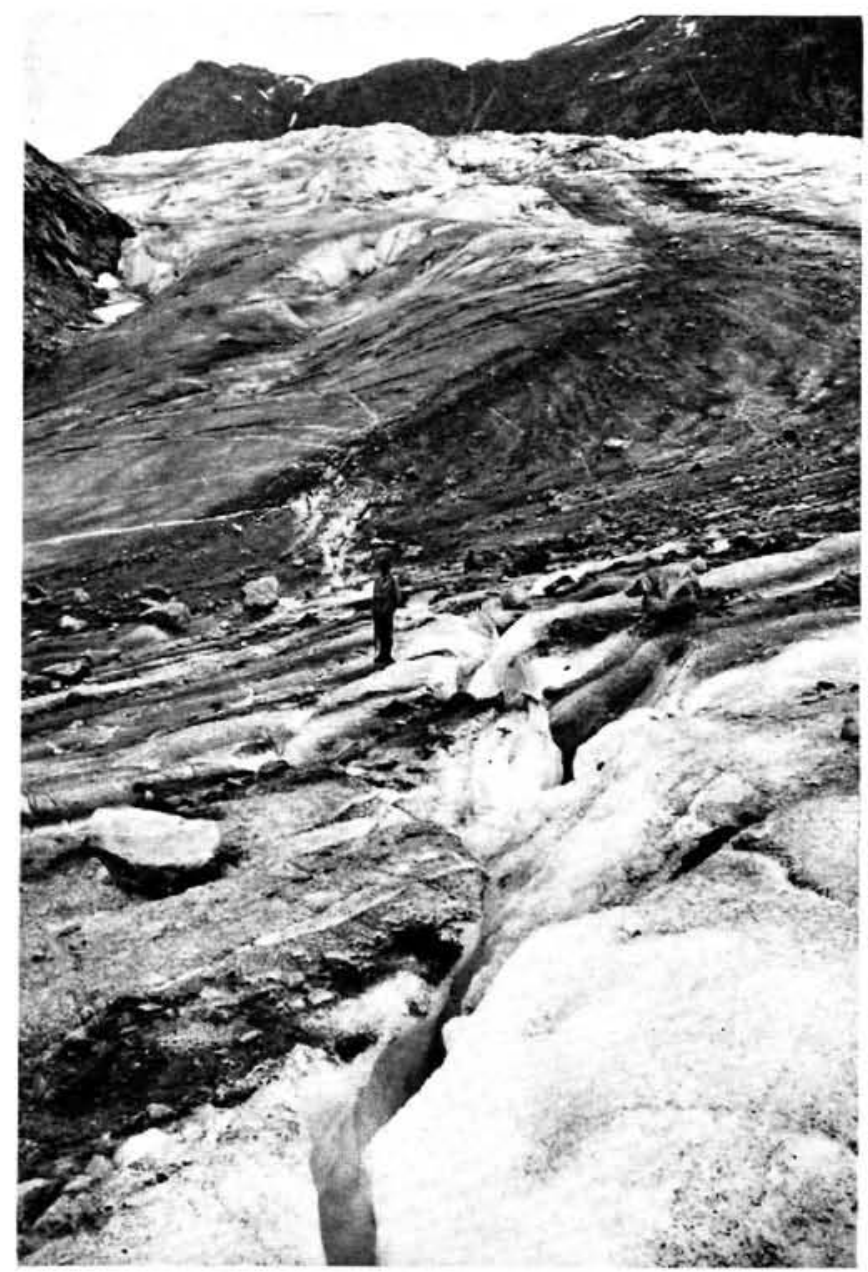

Fig. 4. Part of the irregular crevasse extending to the base of the low ice fall in the middle distance. This crevasse runs at right angles to the normal direction of crevassing in this area. Note the debris of the medial moraine on the surface of the glacier.

crevasses running parallel to the side of the valley were formed, and cracks were developed in snow gullies extending on to the edge of the ice. There was slumping of snow and moraine on to the surface of the glacier.

Upward movement of the ice had occurred in the area where the supraglacial lake had occupied the depression between the ice surface and the valley side, but in what manner the 
lifting of this section of the glacier took place could not be determined. It is possible that the whole section was raised as a single unit. Alternatively, either the crevasse forming the line of dislocation, or the crevasses close to the side of the glacier, could have acled as a "hinge line" about which the verlical movement took place. Whatever the exact mechanism involved, it indicates that forces strong enough to overcome the contact between the glacier and its bed, to cause fracture of the icc, and to lift the ice front, were gencrated.

The final problem is the routc by which the water escaped from Brimkjelen. 'There was no evidence that water escaped directly from the surface of the glacier, and even if it did, this would not have led to complete drainage of the lake. After the lifting of part of the glacier, it would perhaps have been possible for the water to have escaped subglacially from this section of the ice cliff. There was no dircet evidence for this, however, and the mass of icebergs along the front of the ice cliff preverted inspection of the base of the ice. Assuming that this was the means by which the water escaped, there is still the problem of explaining how the water was able to penetrate the portion of the glacier that had not been raised up.

An oblique acrial photograph of Brimkjelen (Licstel, 1956, p. 135) shows that in 1954 the entrance of a tunne] was visible at the base of the ice cliff. 'This tunnel occurred at the lowest part of the valley floor, and it is possible that in 1962 the lakc drained once again by way of this former route. In this area, towards the southern side of the valley, collapse of the ice was much more extensive in 1962 than along the remainder of the ice cliff. Large scctions of the ice had subsided, rather than individual picces breaking off the ice cliff. 'T he collapse of the ice could have resulted from a lifting of this part of the ice barrier to initiate drainagc, or alternatively, could have resulted from the release of water pressure against the ice cliff, after drainage had occurred.

\section{Discussion}

From the historical records available, it is evident that drainage of the lake followed the pattern suggested by Thorarinsson $(1939$, p. 223). He considers that an ice-dammed lake experiences three stages during the general wastage and retreat of a glacier. Initially the lake is permanent; this is followed by a period of outbursts from the lake, which gradually diminish in intensity as the damming effect of the ice barrier becomes weaker, and finally the lake ceases to refill and a permanent outlet is maintaincd. It seems likely that in 1962 drainage from the lake had not completely attained the third stage suggested by 'Ihorarinsson.

Thorarinsson (1939) has suggested that drainage from an ice-dammed lake is initiated by lifting of the ice barricr, once the critical level is reached. This critical level is attained when the water is deep enough for the ice barricr to float and overcome the contact between the glacicr and its bed. As an example, Lindsay ( 966, p. 443) observed that 94 per cent of the ice cliff of an ice-dammed lakc on the Casement Glacier, Alaska, was covercd by water, before the ice barricr was lifted to allow the water to escape. From observations of Brimkjelen, it appears that in this case the critical level for floatation of the glacier was exceeded along part of the ice cliff, with water overflowing on to the surface of the glacier. All parts of the ice cliff may not necessarily experience the forces of floatation at the same time, because of the variations in height of the surface of the glacier in this area. 'l hus, the lower parts of the glacier, close to the valley sides, could undergo strong forces of uplift before the water could reach the critical level in the higher, central parts of the ice cliff.

Glen (I 554, p. 3I8) has criticized the suggestion that an ice-dammed lake will drain completely after the ice barrier has been lifted. Once the level of the water in the lake falls below nine-tenths of the height of the ice barrier, the glacier will no longer be floating and outflow is likcly to be prevented. From experiments on the mechanical properties of ice he has suggested that drainage may start when the water in the icc-dammed lake opens a tunnel as a result of the pressure of the water exceeding the pressure of the ice. 
Liestol (1956, p. 123-25) has suggested that movement of a glacier over an irregular surface will open small cavities under the ice sufficient to allow water to penetrate and start the drainage from the lake. Once the water begins to flow, the tunnel under the ice will be widened by melting as a result of a heat surplus if the temperature of the water is above zero degrees Celsius. The oblique aerial photograph of Brimkjelen in 1954 (Liestol, 1956, p. 135) indicates that drainage from the lake has been through a tunnel overlain by almost $100 \mathrm{~m}$ of ice.

From the observations at Tunsbergdalsbreen, it is evident that both floatation of the ice (Thorarinsson, 1939) and the formation of a subglacial tunnel (Glen, 1954; Liestol, 1956) have occurred, and it is suggested that drainage from the ice-dammed lake may be produced by a combination of these two processes. When the critical level was reached in the central parts of the ice cliff, uplift of the ice barrier would allow subglacial penetration of the water. The pressures then exerted by the water beneath the ice could have initiated drainage through the former subglacial stream course in the bottom of the valley.

\section{ACKNowledgements}

The author would like to thank the members of the Brathay Exploration Group who have participated in this work; in particular, A. B. Ware, Director of the Brathay Field Studies Centre, and W. G. Jenkins and R. J. Lorimer, leaders of the 1962 Tunsbergdalsire Expedition.

MS. received to November 1967 and in revised form 2 . May 1968

\section{REFERENCES}

Glen. J. W. 1954. The stability of ice-dammed lakes and other water-filled holes in glaciers. Journal of Glaciology. Vol. 2. No. 15, p. 316-18.

Ingstad. O. 1927. Flommen fra Brimkjelen. Norske Turistforenings Arbok. 1927, p. 138 41.

Kick. W. 1966 . Long-term glacier variations measured by photogrammetry. A re-survey of Tunsbergdalsbreen after 24 years. Joumal of Glacio!ngy. Vol. 6. No. 43: p. 3 -18.

Liestol, O. 1956 . Glacier dammed lakes in Norway. Norsk Geografisk Tidsskrift. Ld. 15. 11. 3 +. 1955 5. p. 122 49 .

Lindsay. J. F. 1966. Observations on the level of a self-draining lake on the Casement Glacier. Alaska. Joumal of Glacislogy. Vol. 6. No. 45 . p. 44345 .

Otnes. J.. and Ostrem, G. 1967 . Tunsbergdalsbreen, 1 : 20,000: a newe glacier map of a part of the Jostedalsbreen ice cap. Oslo. Norges Vassdrags- og Elektrisitetsvesen, Hydrologisk Avdeling.

Pillewizer. W. 1952. Beobachtungen am Jostedalsbre in Sudnorwegen. Zeitschrift für Gletscherkunde und Glazialgeologie, Bd. 2, Ht. 1, p. 25-34.

Rekstad. J. 1901. Opdamning ved Tunsbergdalsbraen i Sogn. Naturen, 25 Årg.. p. 81-87.

Rekstad. J. 1904. Opdamning ved Tunsbergdalsbraen i Sogn. Natien. 28 Arg.. p. 1-6.

Rekstad. J. 1911. Kurze Übersicht uber die Gletschergebiete des südlichen Norwegens. Bergens Mitserms Aarbok. 1911. 2det Ht.. [article] 7 .

Thorarinsson. S. 1939. The ice-dammed lakes of Iceland, with particular reference to their values as indicators of glacier oscillations. Geografiska Annaler, Arg. 21, Ht. 3-4, p. 216-42. 